\title{
Xenostrobus securis (Lamarck, 1819) (Mollusca: Bivalvia): first report of an introduced species in Galician waters
}

M. E. Garci - J. E. Trigo - S. Pascual - A. F. González - F. Rocha - A. Guerra

\author{
M. E. Garci - S. Pascual - A. F. González - F. Rocha - A. Guerra
}

Instituto de Investigaciones Marinas, ECOBIOMAR, Eduardo Cabello 6, 36208 Vigo, Spain

e-mail: brc1@iim.csic.es

J. E. Trigo

Fray Rosendo Salvado, $133^{\circ} \mathrm{S}$,

15701 Santiago de Compostela, Spain

\section{Abstract}

The presence of the non-indigenous species, the black-pygmy mussel Xenostrobus securis, is reported here for the first time in an intense shellfish farming area off Galicia (NW Spain). Very high concentrations of this mytilid bivalve have colonized estuarine waters located at the inner part of the Ria de Vigo. The invasive role of X. securis is discussed in the context of the wide ecological tolerance of the species and the recent finding of settlements of this species on numerous colonies of the economicallyimportant blue mussel Mytilus galloprovincialis. The mode of introduction of the blackpygmy mussel is also discussed in relation to human management activities.

Keywords Mytilus galloprovincialis - Shellfish farming - Ria de Vigo - Xenostrobus securis

Introduction

Since the 1990s biological invasions have captured the attention of the scientific community as an important element of global change and a major threat to native biodiversity (Mack et al. 2000). According to Morton (1996) invasive bivalves have an ideal biological design for colonizing new environments, including an euryecius and 
eurytopic condition, short-life span, rapid growth and maturity, high fecundity and genetic variability, gregarious behaviour and some form of association with human activities. The black-pygmy mussel Xenostrobus securis has many of these characteristics, which may ultimately result in this species becoming a potential pest bivalve with a negative impact on the ecosystem where it is introduced (Darrigran 2002). This species is a small brown mussel endemic to the brackish waters of New Zealand and Australia (http://www.ciesm.org). It has also been reported to be an invading species in Italian coastal lagoons (Lazzari and Rinaldi 1994; Sabelli and Speranza 1994), the Po River delta (Russo 2001), French Mediterranean lagoons and in Japanese waters (Kimura et al. 1999; Kohama et al. 2001). The historical introduction of various alien molluscan species in Galician waters is known to many malacologists, especially in estuaries supporting highly productive shellfish farming (Rolán et al. 1985).

The aim of the investigation reported here is to document for the first time the establishment of the black-pygmy mussel in Iberian Peninsular waters.

Material and methods

Three sampling sites were located near the mouth of the Verdugo river in the inner inlet of Ria de Vigo (Fig. 1): Station 1, on the lower course of the river, near Sotomayor; Station 2, near the mouth of the river, in the inner part of the Arcade; Station 3, $2 \mathrm{~km}$ from the river mouth, in the outer part of the Arcade, near Piñeiro inlet). The sampling was carried out in September 2005.

The geographic distribution, substrata type and population density were recorded at each sampling station by scuba diving. Three wild colonies was sampled along three different transects from the river to the estuary. Three 20 x 20-cm squares were sampled in each transect. The collected specimens were transported to the laboratory, counted and measured. The data obtained were extrapolated to the number of individuals per square meter.

A randomly collected sample of 30 black-pygmy mussels were reared for 1 month in each of four 50-1 tanks in a re-circulation culture system maintained at room 
temperature. Mussels were fed on an algal diet of Isochrysis galbana (G-Iso). Survival rates were recorded for each tank. The water of each tank was maintained at different salinity, namely 5-10 psu, 15-20 psu and 25-30 psu. The former two salinities are within the range found in the lower course and the mouth of the Verdugo River (1.40 psu at the surface and 23.52 psu at the bottom), and the latter salinity corresponds to the inner inlet waters of the Ria de Vigo (25.91 psu at surface and 27.51 psu at bottom). About 15 individuals from each of the three groups were placed in a tank containing water at the salinity of 35-36 psu, which is similar to that found in the outer part of the Ria de Vigo.

Results

\section{Diagnosis}

Taxonomic diagnosis of fresh specimens first indicated Modiolus barbatus (Linnaeus). However, a further detailed study based on shell morphology (e.g. shell equivalve; subcylindrical; ventral margin straight or slightly arcuate; umbones nearly terminal; shell dark brown; internally, the shell is usually pearly, purple above and white below the umbonal keel; periostracum shining and hairy in younger specimens) ultimately resulted in the molluscs being identified as Xenostrobus securis. This specific diagnosis was confirmed by three other Spanish malacologists: E. Rolán (Luis Iglesias Museum of Natural History), J.M. Vieitez (University of Alcalá) and C. Salas (University of Málaga).

\section{Ecology}

Field sampling revealed that the black-pygmy mussel is currently restricted to the upper reaches of estuaries in the inner part of Ria of Vigo. Numerous colonies at very high concentrations were found at the three sampling stations, with a dispersal up to the Piñeiro's inlet. Preliminary field observations recorded in 2002 noted that the presence of the black-pygmy mussel was restricted to the release area of the inner part of the Piñeiro’s inlet, at the point where the Verdugo River flows into it. By 2005, these mussels had spread from $5.5 \mathrm{~km}$ up-river (i.e. Sotomayor, Station 1) to the outer part (2 km from the mouth of the river) of the Piñeiro’s inlet (i.e. Arcade outer, Station 3). 
Population densities have clearly increased in the last 3 years. The present standing stock is $67,000 \pm 1300$ individuals $/ \mathrm{m}^{2}$ at Station 1 and $8,700 \pm 550$ individuals $/ \mathrm{m}^{2}$ at Station $2\left(14,300 \pm 840\right.$ individuals $/ \mathrm{m}^{2}$ on rocky substrates and 3,100 \pm 320 individuals $/ \mathrm{m}^{2}$ on muddy bottoms). Population densities were related to the size of the mussel. Mussels from Station 1 had an average shell length of $11.0 \pm 0.9 \mathrm{~mm}(\mathrm{n}=50)$. Individuals from the rocky substrata at Station 2 were significantly larger (shell length: $28.0 \pm 3.2 \mathrm{~mm} ; \mathrm{n}=50 ; \mathrm{t}=12.69, \mathrm{p}<0.01$ ) than those sampled from Station 1 . The muddy bottom specimens from Station 2 were the largest (shell length: $46.4 \pm 2.0 \mathrm{~mm}$; $\mathrm{n}=50$ ). At Station 3, the average shell length (size) of the black-pygmy mussels was $39.2 \pm 2.6 \mathrm{~mm}(\mathrm{n}=50)$. Mussels from all stations had average ratios of 0.37 (height/length) and 0.49 (width/length).

The population density of black-pygmy mussels at Station 3 was 4,766 \pm 470 individuals/m; 85\% (571 specimens) of the individuals in the three $20 \times 20 \mathrm{~cm}$ squares sampled at that station had settled on colonies of the blue mussel Mytilus galloprovincialis (Fig. 2a, b).

Large concentrations of black-pygmy mussels were found to have settled on a variety of hard substrates, both natural (rock) and artificial (free trunks, branches, tubes, walls, etc.), but these mussels had also colonized directly on sandy or muddy bottoms. A preliminary observation showed that size and population density changed with water depth. The black-pygmy mussel was far more abundant and larger in size in deeper colonies of the infralitoral waters than in shallow intertidal waters. There appeared to be a vertical displacement by $\mathrm{X}$. securis of $\mathrm{M}$. galloprovincialis to the intertidal upper rocky substrata (Fig. 2c).

In the laboratory, survival rates of $100 \%$ were found in all of the mussel groups exposed to the different salinity concentrations. Some individuals of the experimental groups cultured at salinities of 20-25 psu and 35-36 psu were noted to be rather active, with rapid displacement to the upper part of the tank through very active deployment of byssal threads.

\section{Discussion}


Although no data are available on the dispersal or mechanisms of how $\mathrm{X}$. securis has spread in the sampling area, field observations suggest that this species is overcoming the sequential transitions of the invasion process successfully. An increased population density of this mytilid in recent years and its appearance in new estuarine habitats indicate a successful invasive role in the Ria de Vigo. Furthermore, the results of our laboratory experiments recorded a rapid mobility and noticeable adaptability of the black-pygmy mussel to different habitat conditions. This species can spread relatively well and tolerates salinities of between 5 psu and 36-37 psu, which may be key factors contributing to its colonization of new habitats (Wilson 1967; Kimura et al. 1995).

This investigation is a preliminary study and is based on only limited observations. Our main goal was to provide a warning or alert signal on the potential dangers that accompany the introduction - and subsequent invasiveness - of this species to the estuarine waters of the Galician Rias. The waters of the Galician Rias produce over 270,000 tonnes of mussels per year, and the invasion history of a pest species is a valuable guide for predicting the consequences of its introduction into a new environment (Ricciardi 2003). We strongly recommend that a more rigorous study be carried out to evaluate the potential impact of (reproductive success and population growth) of this invader in different regimes of turbidity, circulation, temperature and salinity in different areas of the Ria de Vigo, especially those close to shellfish farming sites. A programme is thus needed to critically evaluate the potential economic (e.g. by competition or even displacement of native species of commercially-exploited molluscs, or as a fouling organism) and ecological (e.g. on ecosystem functioning by favouring changes in the recipient communities) impact caused by $\mathrm{X}$. securis in this region. Likewise, it is important to promote studies which help clarify the invasion corridors by defining the pathways, timing and sources of invasion. It is likely that $\mathrm{X}$. secures has been unintentionally introduced in Galician waters via the importation of seeds of oysters from the Mediterranean to shellfish farming areas. In fact, Rolán (1992) and Rolán et al. $(1985,1994)$ recorded a series of non-native molluscan species from the Mediterranean in our sampling area. These authors noted that Galician Rias’ ecosystems are subjected to a high frequency of introductions of alien species, which is likely due to the importation and further culturing in mussel-rafts of clams and oysters from the Adriatic Sea. Greater clarity in our understanding of the mode of introduction and the niche opportunities (as defined by Shea and Chesson 2002) for the establishment and 
spreading of X. securis in the Galician Rias will help us to focus on the potential impact of this invader.

It should be noted that X. securis is considered to be one of the worst invasive alien species in Europe (SEBI2010). In this above initiative (WG 5: Trends in alien species), $\mathrm{X}$. securis was recommended as a priority species for control and management.

Acknowledgements

We specially would like to thank E. Rolán, J.M. Vieitez and C. Salas for their help in species identification. The authors are indebted to two anonymous referees for improving the manuscript.

References

Darrigran G (2002) Potential impact of filter-feeding invaders on temperate inland freshwater environments. Biol Invasions 4:145-156

Kimura T, Kakuta T, Kurokura H (1995) Salinity tolerance and osmoregulation in freshwater and brackish water mytilids (Mytilidae: Genus Limnoperna). Bull Soc Sea Water Scientist Jpn 49:148-152

Kimura T, Masaaki T, Yasuhiro S (1999) Limnoperna fortunei kikuchii Habe, 1981 (Bivalvia: Mytilidae) is a synonym of Xenostrobus securis (Lamarck, 1918): introduction into Japan from Australia and/or New Zealand. Japanese Jpn J Malacol 58:101-117

Kohama T, Montani S, Kajiwara Y, Yamada M (2001) Population dynamics of sessile bivalves Mytilus galloprovincialis and Xenostrobus securis in hyper eutrophicated bay, Japan. Bull Jpn Soc Fish Sci 67:664-671

Lazzari G, Rinaldi E (1994) Alcune considerazione sulla presenza di specie extra Mediterranee nelle lagune salmastre di Ravenna. B Malacol 30:195-202 Mack R, Simberloff D, Lonsdale M, Evans H, Clout M, Bazzaz F (2000) Biotic invasions: causes, epidemiology, global consequences, and control. Ecol Appl 10:689-710 
Morton B (1996) The aquatic nuisance species: a global perspective and review. In:

D’itri F (ed) Zebra mussels and other aquatic species. Ann Arbor, Press, Ann Arbor, pp 1-54

Ricciardi A (2003) Predicting the impacts of an introduced species from its invasion history: an empirical approach applied to zebra mussel invasions. Freshw Biol 48:972-981

Rolán E (1992) Dos especies más de moluscos mediterráneos introducidas en la bahúa de O Grove (Galicia, España). Thalassas 10:135

Rolán E, Trigo J, Otero-Schmitt J, Rolán-Álvarez E (1985) Especies implantadas lejos de su área de distribución natural. Thalassas 3:29-36

Rolán E, Pérez-Sixto JL, García-Caballero R (1994) Nuevas citas de moluscos para la Ría de Vigo. Noticiario de la Sociedad Española de Malacología 20:19-21

Russo P (2001) Grande concentrazione di Xenostrobus securis (Lamarck, 1819) in varie zone del Delta del Po. Conchiglia 298:49-50

Sabelli B, Speranza S (1994) Rinvenimento di Xenostrobus sp. (Bivalvia, Mytilidae) nella laguna di Venecia. B Malacol 29:311-318

Shea K, Chesson P (2002) Community ecology theory as a framework for biological invasions. Trends Ecol Evol 17:170-176

SEBI2010-Streamlining European 2010 Biodiversity Indicators. http://www.biodiversitychm.eea.europa.eu/information/indicator/F1090245995/F1115192484/fol712457 Wilson BR (1967) A new generic name for the three recent and one fossil species of Mytilidae (Mollusca: Bivalvia) in southern Australia, with redescriptions of the species. Publ Malacol Soc Lond 37:279-295 


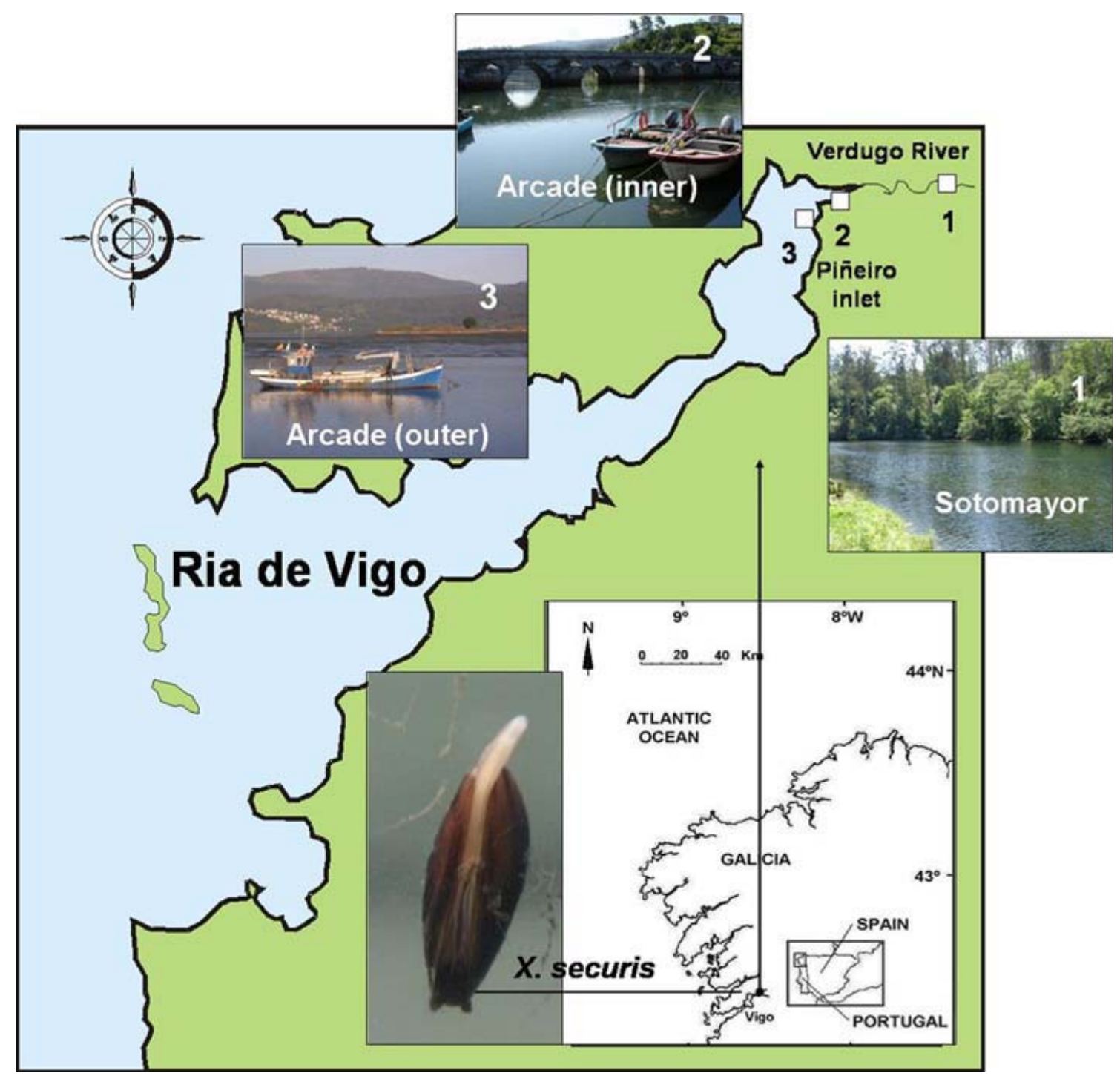

Fig. 1 Sampling stations at the Ria of Vigo 


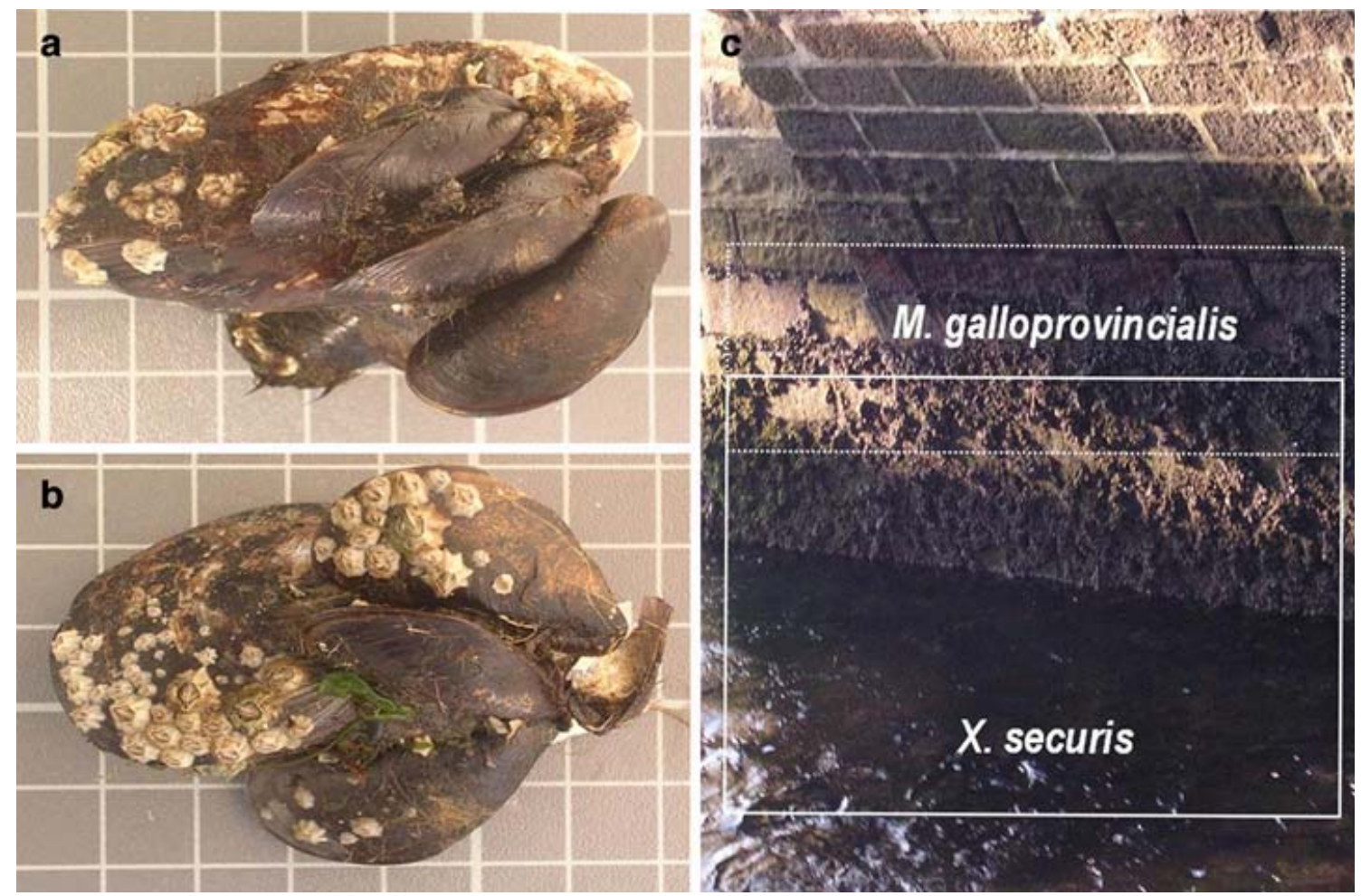

Fig. 2 Settlement of various Xenostrobus securis on Mytilus galloprovincialis (a, b). Vertica distribution of $\mathrm{X}$. securis and M. galloprovincialis in an intertidal rocky substrate (c) 